\title{
Regional Income Inequality in Lithuania
}

The problem of income inequality is globally relevant, receiving the attention of both scientists and politicians. Lithuania as a small country has made significant progress in approaching the standard of living in Western Europe. However, there are still differences in economic growth between separate population groups. Thus, the problem of income inequality remains very acute. Currently, researchers are widely discussing the risk of income inequality to the country's society by analysing its causes and proposing various solutions. Although scientific debates address income inequality across regions, such studies are often limited to examples of large countries. Meanwhile, there is a lack of studies on regional income inequality in small countries, so the question of whether a small country is characterised by regional income inequality remains open. This research aims to examine the level of regional income inequality in Lithuania. We hypothesised that Lithuania has a high level of regional income inequality and this is one of the causes of the high income inequality in the whole country. To estimate regional income inequality, we used the most common measures: Gini coefficient, decile ratio, and the coefficient of variation. The analysis was performed at level 3 of the Nomenclature of Territorial Units for Statistics (NUTS), according to which Lithuania is divided into 10 administrative counties. For this research, we chose the indicators illustrating income per capita on various levels, i.e., gross domestic product (GDP) per capita, average disposable household income per capita, and gross hourly wages, as the various types of income can be used. For the estimation of GDP per capita and average disposable household income, we analysed the data provided by the Lithuanian Department of Statistics (Statistics Lithuania) for 2014-2017. Due to a lack of data to estimate gross hourly wages, we examined the statistical data from the Lithuanian Department of Statistics for 2014. The results show that the hypothesis has not been confirmed. According to the research results, there is a small distribution of income between different regions of a small economy, although the level of economic development of different regions differs. The study findings are important not only from an academic perspective for identifying the causes of income inequality and raising questions for further research, but also for regional economic policy makers. The obtained results show that decisions related to a more equal distribution of income in Lithuania as a small country are determined not only by the specificity of its regions but also by the general trends of the country.

Keywords: Gini coefficient, decile ratio, Lorenz curve, coefficient of variation, income inequality, GDP per capita, average disposable household income per capita, gross hourly wages, administrative counties, Lithuanian Regions

For citation: Laskiene, D., Pekarskiene, I. \& Kontautiene, R. (2020). Regional Income Inequality in Lithuania. Ekonomika regiona [Economy of region], 16(4), 1104-1114, https://doi.org/10.17059/ekon.reg.2020-4-7

${ }^{1}$ (c) Laskiene D., Pekarskiene I., Kontautiene R. 


\author{
Д. Ласкиене ${ }^{\text {a) }}$, И. Пекарскиене б), Р. Контаутиене ${ }^{\text {) }}$ \\ а, б, в) Каунасский технологический университет, Каунас, Литва \\ a) https://orcid.org/0000-0001-5224-5040 \\ 6) https://orcid.org/0000-0001-8710-4731,e-mail: irena.pekarskiene@ktu.lt \\ в) https://orcid.org/0000-0003-1881-3424
}

\title{
Региональное неравенство доходов в Литве
}

Актуальная во всем мире проблема неравенства доходов привлекает внимание как ученьх, так и политиков. Литва как небольшое государство добилась значительного прогресса, приблизившись к уровню жизни стран Западной Европь. Однако до сих пор наблюдаются различия в экономическом росте регионов страны. Таким образом, проблема неравенства доходов носит острый характер. Современные исследователи обсуждают влияние неравенства доходов на общество, анализируют его причины и предлагают различные решения. Существующие научные исследования, рассматривающие региональное неравенство доходов, чаще всего ограничиваются примерами крупных стран. Между тем, работ, посвященных изучению регионального неравенства доходов в небольших странах, немного, и вопрос о существовании подобного неравенства в этих странах остается открытым. Цель данной статьи - изучить региональное неравенство доходов в Литве. Вьгвинута гипотеза, что в Литве существует высокий уровень регионального неравенства доходов, который является одной из причин существенного неравенства доходов во всей стране. Для оценки регионального неравенства доходов были применены наиболее широко используемье показатели: коэффициент Джини, децильный коэффициент и коэффициент вариации. Анализ проводился на 3 уровне Номенклатуры территориальных единии для целей статистики (NUTS), в соответствии с которой Литва делится на 10 уездов. Для исследования были выбраны показатели дохода на душу населения на различных уровнях (в зависимости от типа дохода): валовой внутренний продукт (ВВП) на душу населения, средний доход домохозяйства на душу населения и почасовая зарплата брутто. Для оценки ВВП на душу населения и среднего дохода домохозяйств были проанализированы данные Департамента статистики Литвы за 2014-2017 годы. Из-за отсутствия данных для оценки почасовой зарплаты брутто были изучены статистические данные Департамента статистики Литвы за 2014 год. Результаты анализа показали, что выдвинутая гипотеза не подтвердилась. Согласно выводам исследования, в экономике Литвы существует лишь небольшая разница в распределении доходов между регионами, хотя уровень экономического развития регионов различается. Результаты исследования имеют не только теоретическую (выявление причин неравенства доходов и постановка вопросов для дальнейших исследований), но и практическую иенность (формирование региональной экономической политики).

Ключевые слова: коэффициент Джини, децильный коэффициент, кривая Лоренца, коэффициент вариации, неравенство доходов, ВВП на душу населения, средний доход домохозяйства на душу населения, почасовая зарплата брутто, уезды, регионы Литвы

Для цитирования: Ласкиене Д., Пекарскиене И., Контаутиене Р. Региональное неравенство доходов в Литве // Экономика региона. 2020. Т. 16, вып. 4. С. 1104-1114. https://doi.org/10.17059/ekon.reg.2020-4-7

\section{Introduction}

Income inequality, as shown by various researchers and practitioners, makes a significant contribution to people's quality of life and the overall socio-economic development of the country. Income inequality can be regarded as an important factor in the reduction of social exclusion, whereas its reduction helps achieve social justice. Income inequality exists in all societies, so it is important to assess its extent and various social phenomena in the context of these areas. High income inequality is generally associated with the shadow economy, higher criminality, higher social exclusion and other unwanted phenomena.

Although the problem of income inequality is present worldwide, it is particularly relevant for transition economies moving from central planning to a market economy. Income inequality in transition economies was analysed by nu- merous researchers [1, 2, 3, 4, 5]. As Malkina [4] stated, the uneven economic and social development of country's regions results in regional income inequality. The conducted study has shown that there is income inequality in Russia, both within and between regions. Vasilyeva [5] revealed similar findings. She found that regional uneven economic and social development has a major impact on the quality of life and income inequality.

According to the data of the Lithuanian Department of Statistics ${ }^{1}$, Eurostat ${ }^{2}$, the World

\footnotetext{
${ }^{1}$ Statistics Lithuania. Retrieved from: https://osp.stat.gov.lt/lt_ LT/statistiniu-rodikliu-analize\#/ (Date of access: 10.01.2019).

2 Eurostat. Retrieved from: https://ec.europa.eu/eurostat/ search?p_auth=lBVgpaq3\&p_p_id=estatsearchportlet_ WAR_estatsearchportlet\&p_p_lifecycle $=1 \& p \_p \_s t a t e=$ maximized\&p_p_mode=view\&_estatsearchportlet_WAR_estatsearchportlet_action=search \&text=Income+inequality+in+the+EU (Date of access: 10.01.2019).
} 
Bank $^{1}$ and the $\mathrm{OECD}^{2}$, Lithuania is one of the countries where the level of income inequality is high compared to other European countries. Considerable attention is paid to the issue of income inequality and its difficulties. One of the reasons for income inequality could be the different development of country's regions that led to an uneven income distribution between them. Scientific studies have shown that regional and interregional income inequalities exist in large countries. The question arises as to whether this situation is typical of a small country's economy.

In recent decades, the regional distribution of income within countries has attracted considerable interest among researchers and policymakers. During their studies, researchers were looking for the main causes and determinants of regional inequality. Conflicts, ethnicity and geography are few factors that academics consider relevant for the interregional inequality. Because this issue is important for the economy in particular and society in general, conducted empirical studies have produced interesting and instructive results. Maknickiene et al. [6] have found big differences between Lithuanian regions considering the most important factors of regional economic growth and investments. However, the issue of regional income inequality was not discussed in their study.

Although Lithuanian researchers $[7,8,9,10$, 11] devoted considerable attention to income inequality by analysing it in different terms, there is still a lack of studies on income inequality of Lithuanian regions.

The purpose of this research is to measure regional income inequality in Lithuania.

The results of this study could be important from an academic perspective, ascertaining the causes and consequences of income inequality. Additionally, they can enable policy makers to differentiate their decisions regarding a more equal income distribution between Lithuanian regions.

\section{Literature Review of Income Inequality Theory}

Income inequality is associated with many aspects of social development. Poverty, higher rates of health and social problems, lower chances to access better education, violence, stress and mental issues are among the most common negative consequences caused by income inequality. Wright

\footnotetext{
1 The World Bank open data. Retrieved from: https:/data. worldbank.org/indicator/SI.POV.GINI? end $=2016 \&$ loca tions $=$ XM\&start $=2016 \&$ view $=$ map (Date of access: 10.01 .2019 ) 2 OECD Data. Retrieved from: https://data.oecd.org/searchresults/?q=inequality+of+income (Date of access: 10.01.2019).
}

[12] distinguishes five main reasons why a more equal income distribution is desired by society:

1) Unequal income distributions cause more social problems than relatively equal distributions.

2) Unequal distributions of wealth and income in the present generation generate inequalities in opportunities for future generations.

3) Large differences in the real freedom of people could emerge because of income and wealth inequalities. Some people live off returns on capital investments. They have much more freedom and autonomy than people who have to enter the labour market to earn a living.

4) Larger income and wealth inequalities destroy democracy by providing some people more resources to influence political processes.

5) Income inequality separates community, promotes envy and weakens social solidarity.

According to Di Falco [13], income inequality is a complex phenomenon that arises from the interaction of various factors. Income inequality can be influenced by the region, gender, education, religious views, social status, and other factors.

The phenomenon of income inequality and its implications were examined especially by Stiglitz [14], Palley [15], Baek and Gweisah [16]. The main problems analysed by the authors in academic literature were the identification of the main causes of income inequality $[17,18,19]$, the measurement of inequality $[20,21]$, and the influence of income inequality on economic growth $[22,23,24]$ and social development $[25,26,8,27,5]$.

According to Bourguignon and Morrison [28], it is not appropriate to assess income inequality worldwide between individuals: countries are not identical and income differences exist between countries or even within them. A level of income per citizen is usually indicated by gross domestic product $(G D P)$ per capita. Therefore, the issues of income inequality are usually based on comparative investigations of different countries. In the academic literature, a lot of attention is focussed on studying a country's income inequality by performing cross-regional comparisons [29, 30, 5, 31, 4].

\section{Methodology}

The results of different studies [23, 24, 10, 17] confirmed that there is a dependency between economic growth and income inequality in a country. It shows that economic factors influence income inequality.

Although Lithuania is a small country, there is still uneven economic development in the regions. The study conducted by [6] showed that there are significant regional differences in terms of eco- 
nomic growth. Due to the fact that the regions of Lithuania are uneven in terms of economic development, it was hypothesised that there are large interregional income disparities in Lithuania. This hypothesis was tested by calculating regional income inequality indicators.

The research is based on comparative statistical data analysis, calculation of special coefficients and the use of a graphical method. We considered Lithuanian regions classified by the level 3 of the Nomenclature of Territorial Units for Statistics (NUTS), according to which Lithuania is divided into 10 administrative counties: Alytus, Kaunas, Klaipeda, Marijampole, Panevezys, Siauliai, Taurage, Telsiai, Utena, and Vilnius. In addition, the analysis was performed on NUTS 2 level, according to which Lithuania is divided in two major regions: Capital Region and Central-Western Lithuania Region.

The most commonly used measures for assessing inequality are the Gini coefficient (GINI), decile ratio (R10:10) and coefficient of variation (CV). The Gini coefficient shows the general level of income. The decile ratio calculates the difference in income between mean income of the top 10 percent and mean income of the bottom 10 percent. The coefficient of variation shows how income changes compared to the average of the population income. There are obvious economic differences between the Capital Region and the rest of Lithuania.

We proposed a new indicator to assess income inequality, which measures the difference in income inequality between regions classified at NUTS 2 level in this research. This relative indicator shows the income difference between the most economically developed Capital region and the remaining Central-Western region; it is named a regional coefficient.

The Gini coefficient was developed by C. Gini in 1912. It is linked to the representation of income inequality through the Lorenz Curve. The Gini coefficient is the ratio of the area between the observed Lorenz Curve and the line of perfect equality (the concentration area) to the area of maximum concentration. Figure 1 provides the visual representation of these areas [32].

Gini coefficient is calculated [32]:

$$
G I N I=\frac{\text { Concentrationarea }}{\text { Maximumconcentrationarea }}=\frac{O R P}{O P Q} \text {. }
$$

Mathematically, the Gini coefficient is often described as the "relative mean difference", i.e., the average of the difference between every possible pair of values in a given distribution divided by the average value [33]. The mathematical for-

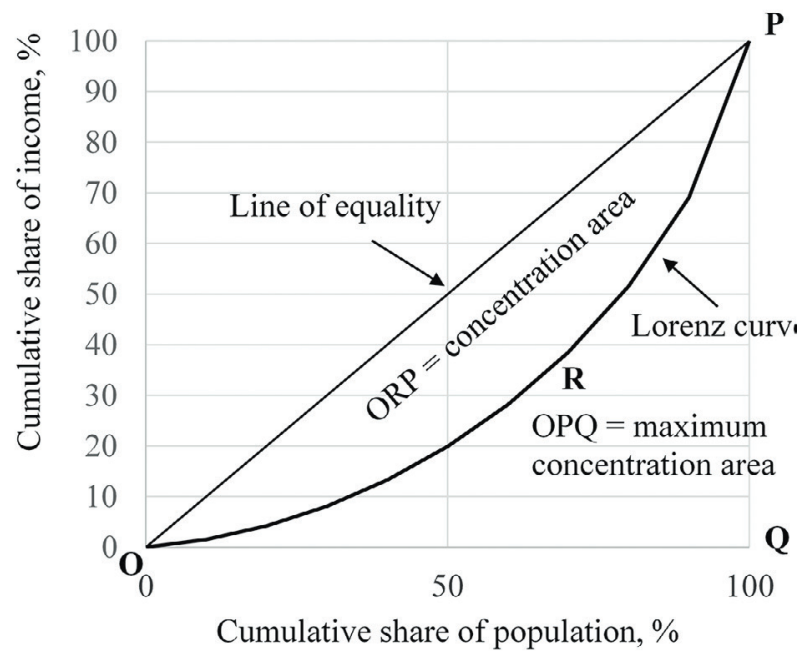

Fig. 1. A typical Lorenz Curve

mula of the Gini coefficient in case of calculating regional income inequality is:

$$
G I N I=\frac{\sum_{i=1}^{n} \sum_{j=1}^{n}\left|x_{i}-x_{j}\right|}{2 n^{2} \bar{x}},
$$

where $x_{i}(i=1,2, \ldots, n)$ is the income of the $i$ region, $x_{i}(j=1,2, \ldots, n)$ is the income of the $j$ region, $\bar{x}$ is the average income.

The Gini coefficient of 0 means perfect equality, where all values are the same (for example, where everyone has the same income). The Gini coefficient of 1 (or 100 percent) indicates the maximal inequality among values (e.g., for a large number of people, where only one person has all income or consumption, and all others have none, the Gini coefficient will be very nearly $1)$. The higher is the coefficient, the more unequal is the distribution.

According to De Maio [34], a simple but effective way to examine income inequality is to calculate decile ratios. The calculation should be done by taking, for example, the income earned by $10 \%$ of the top households and dividing by the income earned by $10 \%$ of the poorest households. The decile ratio was calculated as the proportion between income of a region with the highest income per capita and income of a region with the lowest income per capita. The coefficient of variation as a measure of income inequality is calculated by dividing the standard deviation of income distribution by its mean. More equal income distributions will have smaller standard deviations, as such, the coefficient of variation will be smaller in more equal societies [34]. The mathematical formula of the coefficient of variation in case of calculating regional income inequality is [35]: 
Coefficient meanings

\begin{tabular}{|l|l|}
\hline \multicolumn{1}{|c|}{ Coefficient } & \multicolumn{1}{c|}{ Explanation of values } \\
\hline Gini coefficient & $\begin{array}{l}\text { Less than } 0.25 \text { - very low level of income inequality } \\
\text { More than } 0.25 \text { but less than } 0.30-\text { low level of income inequality } \\
\text { More than } 0.30-\text { very high level of income inequality }\end{array}$ \\
\hline Decile ratio & The higher is the coefficient, the higher is the level of inequality \\
\hline Regional coefficient & $\begin{array}{l}\text { Under } 10 \% \text { - low level of dispersion } \\
10-20 \%-\text { average level of dispersion } \\
\text { Coefficient of variation }\end{array}$ \\
& $\begin{array}{l}20-30 \%-\text { high level of dispersion } \\
30-50 \%-\text { very high level of dispersion } \\
\text { More than } 50 \% \text { - coefficient does not have a real value }\end{array}$ \\
\hline
\end{tabular}

$$
C V=\frac{\sqrt{\sum_{i=1}^{n}\left(x_{i}-\bar{x}\right)^{2} p_{i}}}{\bar{x}},
$$

where $p_{i}$ is the weight of $i$ region according to its population.

The regional coefficient was calculated by dividing the income of the Capital Region and the income of the Central-Western Lithuania Region.

Table 1 provides explanations of the values of special coefficients discussed in the scientific literature, on the basis of which the calculated coefficients were interpreted.

The data from the Lithuanian Department of Statistics ${ }^{1}$ were used to estimate income inequality. The indicators illustrating income per capita on various levels (GDP per capita, average disposable household income per capita, and gross hourly wages) were chosen for this research because the various types of income can be used. GDP per capita indicates generated income per capita in a country or in a region. Average disposable household income per capita shows income per capita including wages and salaries, and possible social benefits. Gross hourly wages indicate earnings of an individual before deductions. For the estimation of GDP per capita and average disposable household income, we analysed the statistical data provided by the Lithuanian Department of Statistics for 2014-2017. Due to a lack of data for the estimation of gross hourly wages, we examined the statistical data from the analysis conducted by the Lithuanian Department of Statistics in 2014.

\section{Results}

GDP per capita is an important indicator, which helps estimate the level of economic development. Comparing GDP per capita of different Lithuanian

\footnotetext{
${ }^{1}$ Statistics Lithuania. Retrieved from: https://osp.stat.gov.lt/lt LT/statistiniu-rodikliu-analize\#/ (Date of access: 29.05.2019).
}

region, we discovered that the highest GDP per capita was generated in Vilnius County and the Capital Region in 2017 (see Figure 2). These regions' GDP per capita significantly exceed GDP per capita of Lithuania. GDP per capita of Kaunas County and Klaipeda County reached the average level of the country's GDP per capita, however, this indicator for other regions was significantly lower. Therefore, it can be stated that the regional development in Lithuania was uneven and that the country's regions had different economic capacities in 2017.

The analysis of average disposable household income per capita of Lithuanian regions showed the same situation as GDP per capita in 2017. However, the difference in income between Vilnius County and the Capital region from other Lithuanian counties and the region of CentralWestern Lithuania was smaller than in the previous case (see Figure 3).

The analysis of gross hourly wages of Lithuanian regions in 2014 demonstrated that the gap between regions was even smaller. The tendencies remained the same as in the two previous cases. The highest gross hourly wages were observed in Vilnius County and the Capital Region. The indicators in Kaunas County and Klaipeda County were close to the average Lithuania's indicator. The indicators of other counties were lower than Lithuania's gross hourly wages (see Figure 4).

To graphically represent regional income inequalities, we used Lorenz curves. The horizontal axis displays the cumulative share of counties (in percent). The vertical axis displays the cumulative share of income (GDP per capita, average disposable household income per capita and gross hourly wages). The inequality of income between Lithuanian regions can be seen in Figure 5.

According to the distribution of income per capita between Lithuanian Regions, the Lorenz curves were not very distant from the line of absolute equality. This fact implies that various in- 


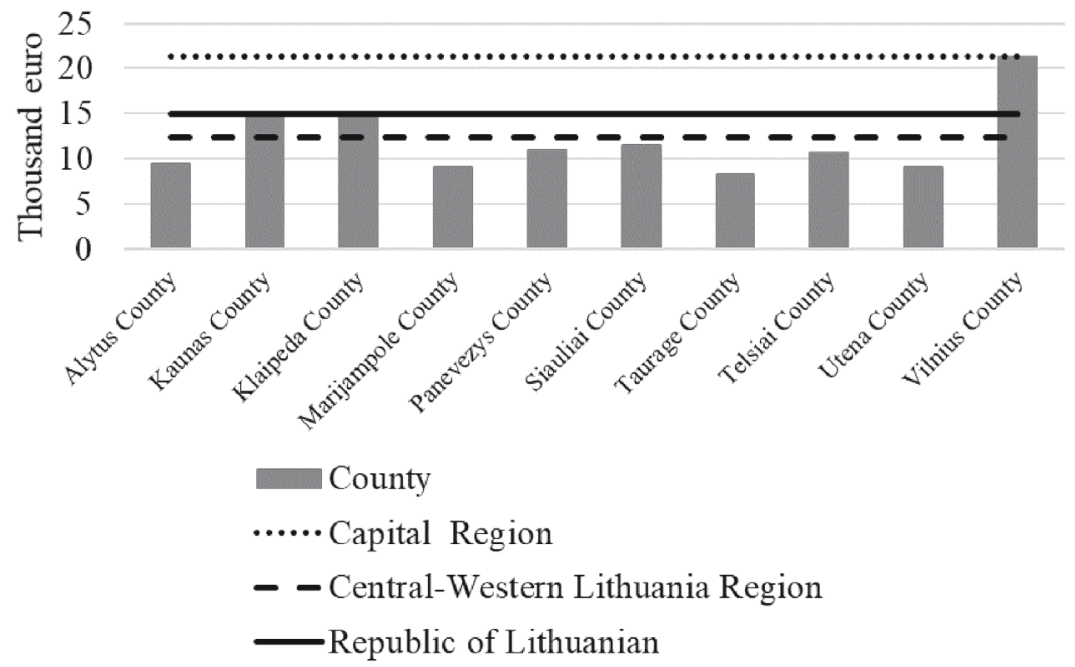

Fig. 2. GDP per capita of Lithuanian Regions in 2017

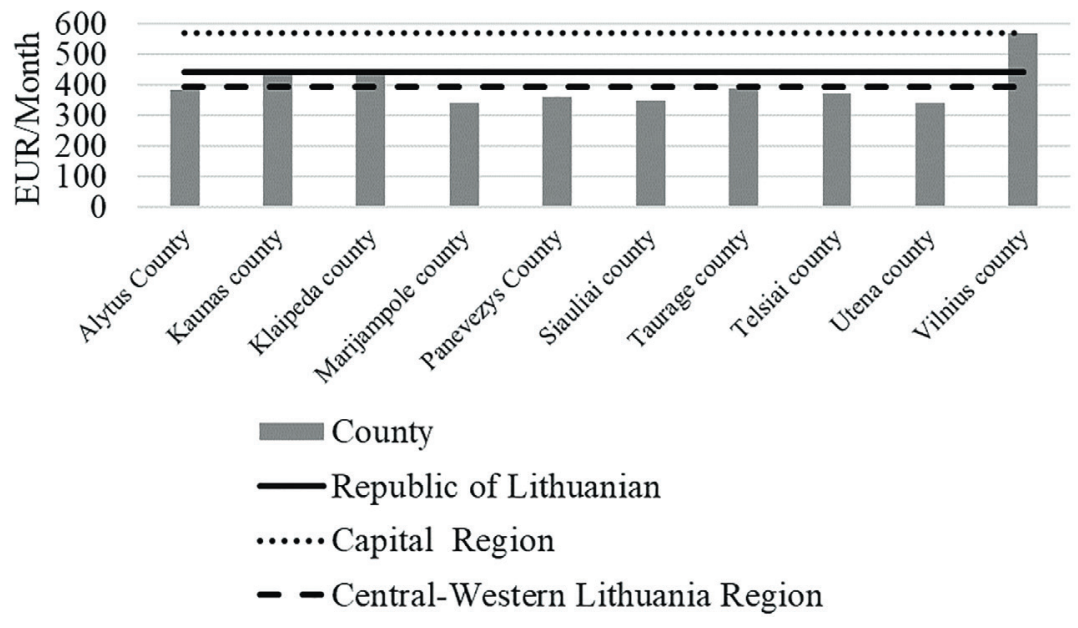

Fig. 3. Average disposable household income per capita of Lithuanian Regions in 2017

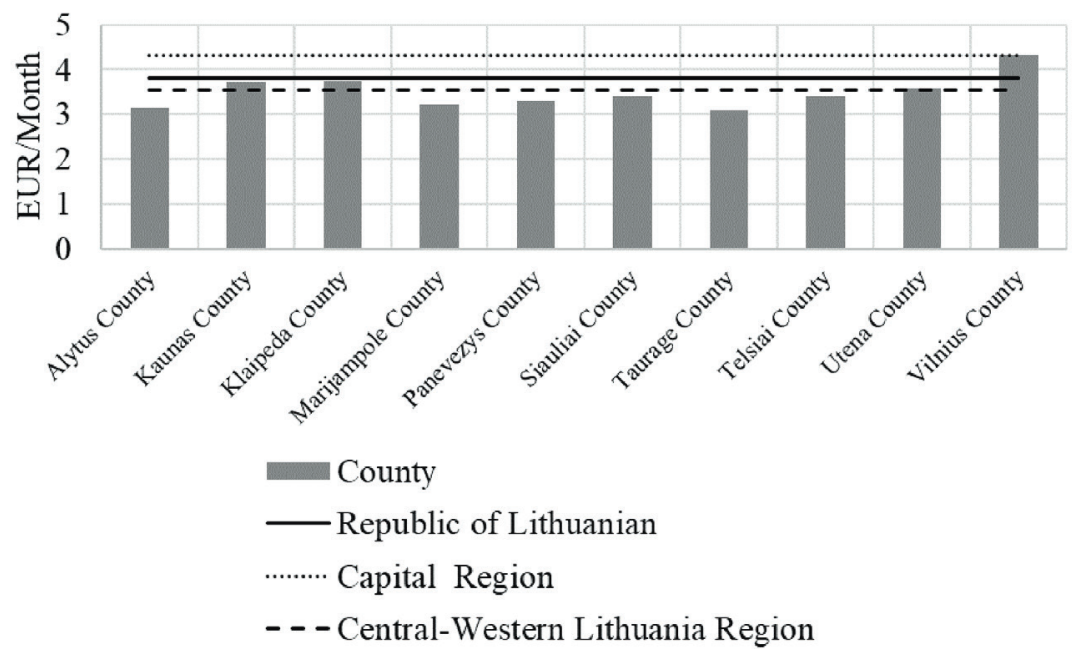

Fig. 4. Gross hourly wages of Lithuanian Regions in October 2014

comes per capita are rather evenly distributed between Lithuanian regions, and that regional income inequality in Lithuania is not high. To confirm this conclusion, we additionally calculated the indicators for measuring income inequality, described in the methodology (see Table 2)
The values of these indicators have been calculated over a period of several years to ascertain that there is no fluctuation in values and highlight their overall tendency.

The values of income inequality coefficients fluctuate little in the period 2014-2017, therefore, 


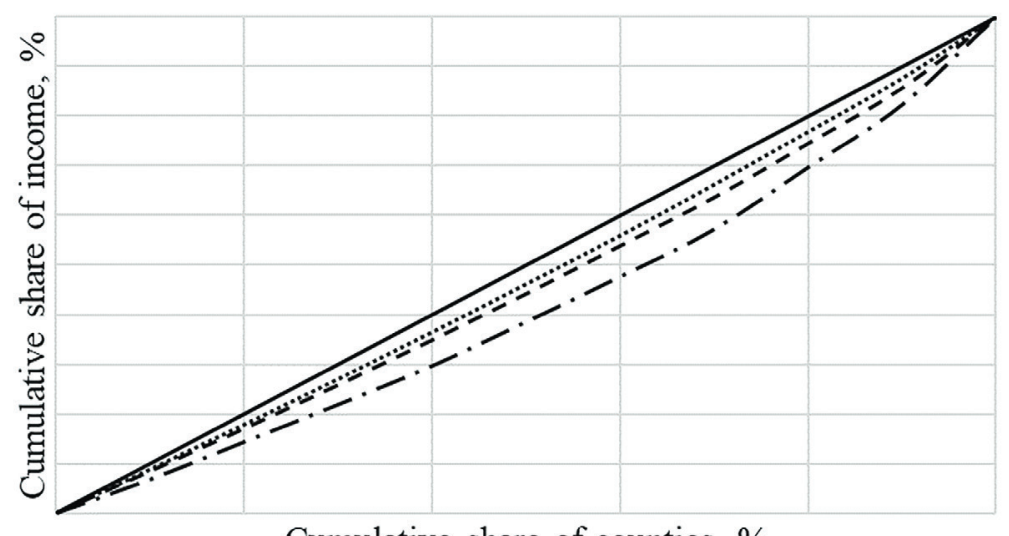

Cumulative share of counties, $\%$

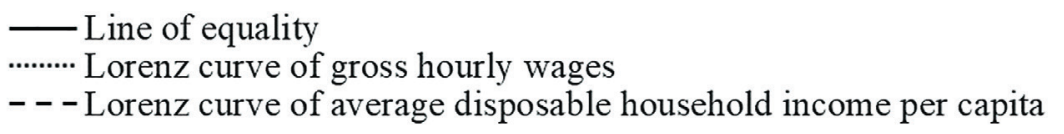

Fig. 5. Inequality of income per capita between Lithuanian Regions

it can be stated that they reflect the general trend prevailing in Lithuanian conditions (see Table 2).

Although the coefficient of variation indicates a very high volatility of added value per capita in the region, which means that in some regions this value deviates from the Lithuanian average by more than $30 \%$, average disposable household income per capita differs only by

Indicators of income inequality between Lithuanian regions and their values

\begin{tabular}{|c|c|c|c|c|c|c|}
\hline Coefficient & Type of income & $\begin{array}{c}\text { Value } \\
\text { in } 2014\end{array}$ & $\begin{array}{c}\text { Value } \\
\text { in } 2015\end{array}$ & $\begin{array}{c}\text { Value } \\
\text { in } 2016\end{array}$ & $\begin{array}{c}\text { Value } \\
\text { in } 2017\end{array}$ & Interpretation of the value \\
\hline \multirow{3}{*}{$\begin{array}{l}\text { Gini } \\
\text { coefficient }\end{array}$} & GDP per capita & 0.1570 & 0.1609 & 0.1663 & 0.1635 & Low level of income inequality \\
\hline & $\begin{array}{l}\text { Average disposable house- } \\
\text { hold income in capita }\end{array}$ & 0.0704 & 0.0916 & 0.0977 & 0.0919 & Low level of income inequality \\
\hline & Gross hourly wages & 0.0538 & No data & No data & No data & Low level of income inequality \\
\hline \multirow{3}{*}{ Decile ratio } & $G D P$ per capita & 2.58 & 2.59 & 2.64 & 2.59 & $\begin{array}{l}\text { Vilnius County's ( } 10 \text { decile) GDP per } \\
\text { capita is about } 2.6 \text { times higher than } \\
\text { GDP per capita of } 1 \text { decile County }\end{array}$ \\
\hline & $\begin{array}{l}\text { Average disposable house- } \\
\text { hold income per capita }\end{array}$ & 1.60 & 1.85 & 1.80 & 1.68 & $\begin{array}{l}\text { Vilnius County's ( } 10 \text { decile) average } \\
\text { disposable household income per cap- } \\
\text { ita is about } 1.8 \text { times higher than indi- } \\
\text { cator of } 1 \text { decile County }\end{array}$ \\
\hline & Gross hourly wages & 1.40 & No data & No data & No data & $\begin{array}{l}\text { Vilnius County's ( } 10 \text { deciles) gross } \\
\text { hourly wages are almost } 1.4 \text { times } \\
\text { higher than Marijampole County's in- } \\
\text { dicator ( } 1 \text { decile) }\end{array}$ \\
\hline \multirow{3}{*}{$\begin{array}{l}\text { Regional } \\
\text { coefficient }\end{array}$} & $G D P$ per capita & 1.76 & 1.76 & 1.75 & 1.72 & $\begin{array}{l}\text { The Capital region's GDP per capita is } \\
\text { about } 1.72-1.76 \text { times higher than the } \\
\text { Central-Western Lithuania Region's } \\
\text { indicator }\end{array}$ \\
\hline & $\begin{array}{l}\text { Average disposable house- } \\
\text { hold income per capita }\end{array}$ & 1.24 & 1.38 & 1.42 & 1.45 & $\begin{array}{l}\text { The Capital region's average dispos- } \\
\text { able household income is } 1.24-1.45 \\
\text { times higher than the Central-Western } \\
\text { Lithuania Region's indicator }\end{array}$ \\
\hline & Gross hourly wages & 1.22 & No data & No data & No data & $\begin{array}{l}\text { The Capital region's gross hourly } \\
\text { wages are } 1.22 \text { times higher than in the } \\
\text { Central-Western Lithuania Region }\end{array}$ \\
\hline \multirow{3}{*}{$\begin{array}{l}\text { Coefficient } \\
\text { of variation }\end{array}$} & GDP per capita & 0.3546 & 0.3018 & 0.30194 & 0.3083 & Very high degree of volatility \\
\hline & $\begin{array}{l}\text { Average disposable house- } \\
\text { hold income in capita }\end{array}$ & 0.1884 & 0.2098 & 0.2622 & 0.1886 & Average degree of volatility \\
\hline & Gross hourly wages & 0.1083 & No data & No data & No data & Average degree of volatility \\
\hline
\end{tabular}




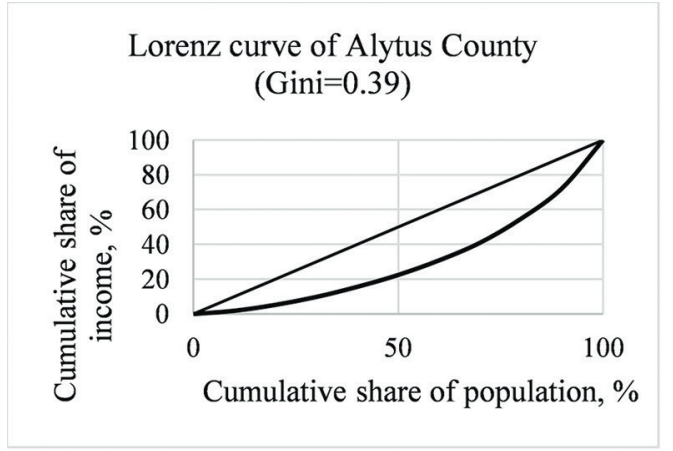

Lorenz curve of Kaunas County

(Gini=0.41)

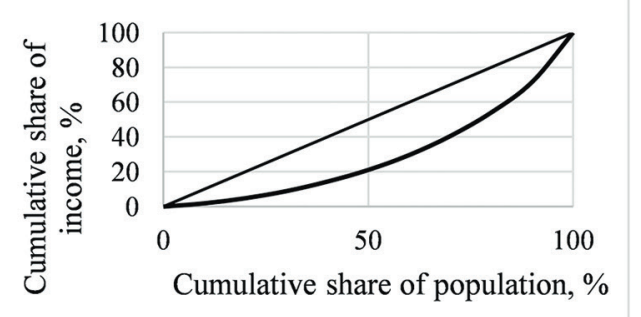

Lorenz curve of Klaipeda County (Gini=0.4)

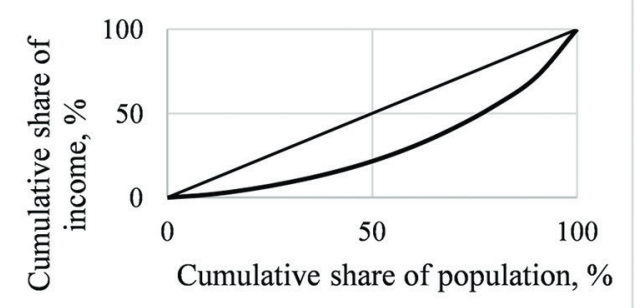

Lorenz curve of Marijampolè County $(\mathrm{Gini}=0.4)$

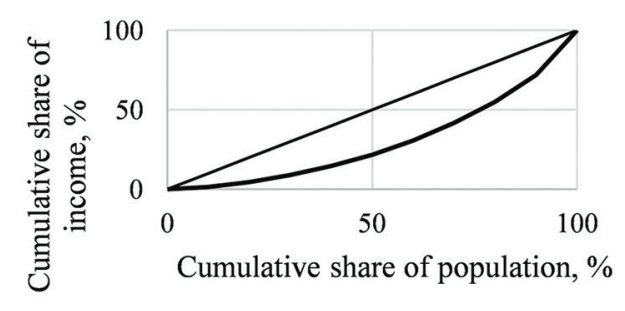

\section{Lorenz curve of Panevėžys County}

(Gini=0.4)

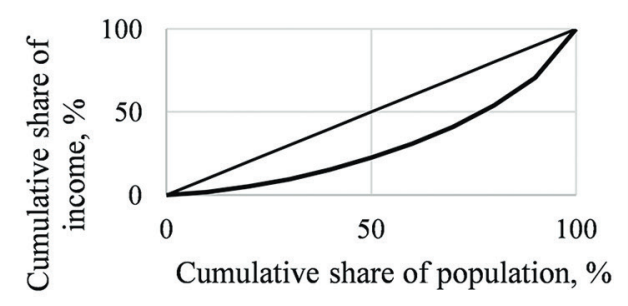

Lorenz curve of Šiauliai County

(Gini=0.37)

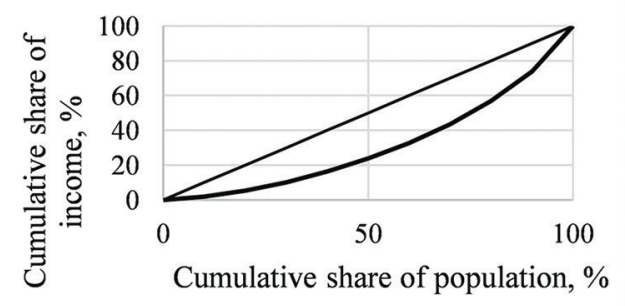

Lorenz curve of Tauragè County

(Gini=0.44)

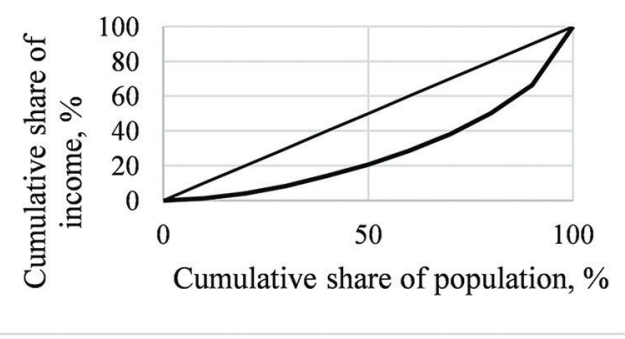

Lorenz curve of Utena County (Gini=0.4)

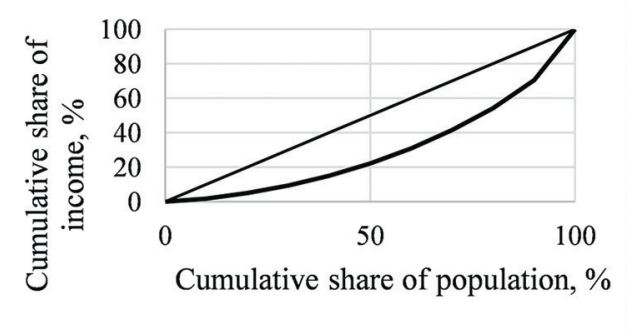

Lorenz curve of Telšiai County

$(\mathrm{Gini}=0.4)$

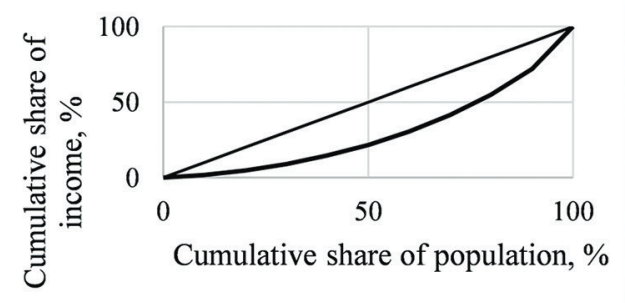

Lorenz curve of Vilnius County

(Gini=0.43)

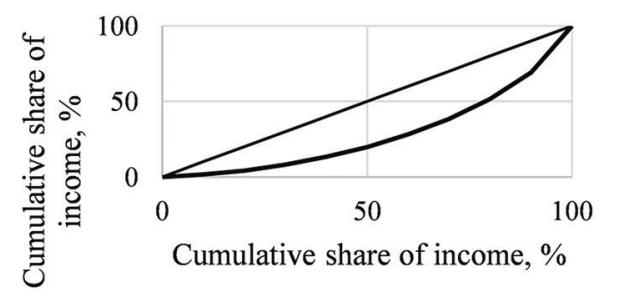

Fig. 6. Inequality of disposable household income in Lithuanian Regions 


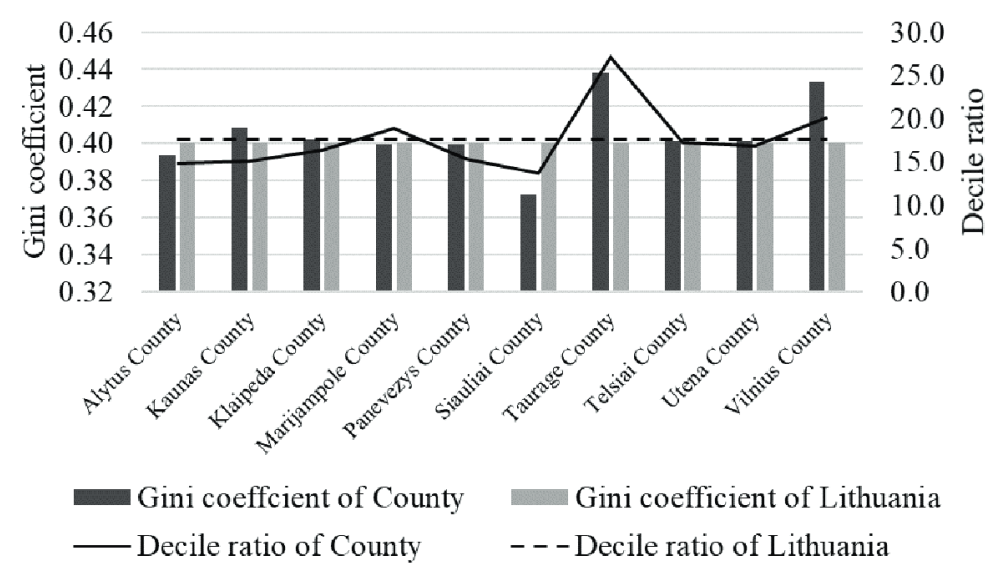

Fig. 7. Values of the Gini coefficient and decile ratio of Lithuanian Regions

$18.9 \%$ and gross hourly wages are even less different $(10.8 \%)$. The average differentiation of income between regions is also shown by the decile ratio and regional coefficient. However, the Gini coefficient indicates a very low income inequality between Lithuanian regions. Depending on the results of the research, it can be stated that although the regions differ in economic development, the hypothesis of the existence of interregional income inequality in Lithuania has not been confirmed. This fact suggests that regional economic disparities are not a major cause of income inequality in Lithuanian regions.

To find the source of the high income inequality in Lithuania, we analysed income inequality within regions. The analysis was based on 2017 household disposable income data, which were broken down into deciles and calculated according to the Gini coefficient and the decile ratio. We have drawn the Lorenz curves for comparison (Figure 6).

Income inequality in individual regions of Lithuania is very high, as all Gini coefficient values are higher than 0.3 (see Figure 6). The lowest income inequality is in Siauliai county (Gini $=0.37$ ), and the highest is observed in Taurage county $(G i n i=0.44)$. The average value of Gini coefficients in all regions is 0.4 , which indicates a very high level of income inequality throughout Lithuania.

Gini coefficient and decile ratio values of individual Lithuanian regions, calculated according to 2017 data on household disposable income, are presented in Figure 7.

The average Gini coefficient of the country is 0.4 , and the average decile ratio is 17.6. Taurage County's values of the Gini coefficient (0.44) and decile ratio (27.1) are the highest. Siauliai County's values of the Gini coefficient (0.37) and decile ratio (13.8) are the lowest. Vilnius County's values of the Gini coefficient (0.43) and decile ratio (20.2) are also high. In other regions, these values are less than the national average (see Figure 7 ).

The analysis of income inequalities within regions confirmed the above statement that the economic development of regions is not the main cause of income inequality in Lithuania. Vilnius County is the strongest and Taurage County is one of the weakest in terms of economic development. Meanwhile, the estimated income inequality indicators (Figure 7) show that income inequality is similar in these regions, and is the highest compared to other regions of the country. It means that income inequality in Lithuania is determined not only by its economic aspect but also by demographic, technological and other factors as well as by the social policy of the country and regions.

\section{Conclusions}

According to the obtained results, there are obvious differences between Vilnius County and other Lithuanian counties as well as between the Capital Region and the Central-Western Lithuanian regions. It can be stated that the added value generated by the population and their income were quite evenly distributed between Lithuanian regions. The implication is that income inequality in Lithuania does not depend on a geographic position or regional economic differences.

According to this research, despite the differences in regional economic development, in a small country like Lithuania, there is a small income inequality between individual regions.

More research is necessary to explain the factors that could reveal the real causes of income inequality in a small country like Lithuania.

High level of income inequality exists within the regions themselves, causing the high level of income inequality in Lithuania. Although income inequality in Lithuanian regions is similar, this is not an argument in favour of the fact that income 
disparities between regions of different economic development are due to the same causes since different economic, demographic and technological processes are observed in regions.
Identifying the causes of income inequality in different regions would enable effective national and regional social policies and other strategic decisions aimed at reducing income inequality.

\section{References}

1. Leiman, V. S. (2010). The distribution of income in a market economy. Vestnik Chelyabinskogo gosudarstvennogo universiteta. Ekonomika [CSU Bulletin. Economic sciences], 28, 37-41. Retrieved from: https://cyberleninka.ru/article/n/ raspredelenie-dohodov-v-rynochnoy-ekonomike/viewer (Date of access: 19.01.2019). (In Russ.)

2. Stukalenko, E. A. (2014). Differentiation of Population's Income: Causes and Consequences. Vestnik Omskogo universiteta. Seriya «Ekonomika» [Herald of Omsk University. Series "Economics"], 1, 183-187. Retrieved from: http://journal.omeco.ru/ru/archive/doc/2014_01/183-187.pdf (Date of access: 18.02.2019). (In Russ.)

3. Sharin, V. I. (2014). The problems of Excessive Income Differentiation of the Population in Russia. Journal of New Economy, 1(51), 38-42. (In Russ.)

4. Malkina, M. Y. (2014). Dynamics and Determinants of Intra and Inter-Regional Income Differentiation of the Population of the Russian Federation. Prostranstvennaya Ekonomika [Spatial Economics], 3, 44-66. DOI: 10.14530/ se.2014.3.44-66. (In Russ.)

5. Vasilyeva, E. V. (2010). Interregional Differentiation of Quality of Life in Russia. Ekonomika regiona [Economy of Region], 4, 234-242. (In Russ.)

6. Maknickiene, N., Lapinskaite, I., Miecinskiene, A. \& Skackauskiene, I. (2018). Patterns of Inequality of Lithuanian Regions. Journal of Business Economics and Management, 19(2), 323-342. DOI: 10.3846/jbem.2018.5574.

7. Lazutka, R. (2003). Population's Income inequality. Retrieved from: http://mokslozurnalai.lmaleidykla.lt/publ/02357186/2003/2/F-22.pdf (Date of access: 19.01.2019). (In Lith.)

8. Skuciene,D. (2008). IncomeInequality in Lithuania. Filosofija. Sociologija [Philosophy. Sociology], 19(4), 22-33. Retrieved from: https://etalpykla.lituanistikadb.lt/object/LT-LDB-0001:J.04 2008 1367163079280/J.04 2008 1367163079280.pdf (Date of access: 29.03.2019). (In Lith.)

9. Ivaskaite-Tamosiune, V. (2013). Income Redistribution in Emerging Welfare Capitalism in Lithuania. Doctoral dissertation. Vilnius: Vilnius University, 254.../......././../../../Asus/Downloads/1923438.pdf (Date of access: 29.01.2019). (In Lith.)

10. Ciegis, R. \& Dilius A. (2015). Assessment of Impact of Income Inequality on Sustainable Economic Growth. In: $D$. Streimikiene (Ed.), Sustainable Development Issues and Its Solutions in Lithuania (pp. 9-50). Vilnius: Vilnius University. (In Lith.)

11. Skuciene, D. \& Kaminaite, G. (2017). The Meanings and Experiences of Income Inequality in Everyday Life. Social Work, 15(2), 101-114. DOI: 10.13165/SD-17-15-2-06. (In Lith.)

12. Wright, E. O. (2000). Reducing Income and wealth Inequality: Real Utopian Proposals. Contemporary Sociology, 29(1), 143-156. DOI: 10.2307/2654939.

13. Di Falco, E. (2014). Income Inequality: Nearly 40 Per Cent of Total Income Goes to People Belonging to Highest (Fifth) Quintile. Statistics in focus 12/2014. Retrieved from: https://ec.europa.eu/eurostat/statistics-explained/index.php?title=Archive:Income_inequality_statistics,_data_2012 (Date of access: 20.04.2019).

14. Stiglitz, J. E. (2016). How to Restore Equitable and Sustainable Economic Growth in the United States. American Economic Review: Papers \& Proceedings, 106(5), 43-47. DOI: 10.1257/aer.p20161006.

15. Palley, T. (2017). Inequality and Growth in Neo-Kaleckian and Cambridge Growth Theory. Review of Keynesian Economics, 5(2), 146-169. DOI: 10.4337/roke.2017.02.02.

16. Baek, J. \& Gweisah, G. (2013). Does Income Inequality Harm the Environment? Empirical Evidence from the United States. Energy Policy, 62, 1434-1437. DOI: 10.1016/j.enpol.2013.07.097.

17. Brunori, P., Ferreira, F. H. G. \& Peragine, V. (2013). Inequality of Opportunity, Income Inequality and Economic Mobility: Some International Comparisons. IZA Discussion Paper, 85-115. DOI: 10.1057/9781137333117_5.

18. Kaasa, A. (2005). Factors of Income Inequality and Their Influence Mechanisms: A Theoretical Overview. University of Tartu Faculty of Economics and Business Administration Working Paper No. 40, 48. DOI: 10.2139/ssrn.868491.

19. Garcia-Penalosa, C. \& Orgiazzi, E. (2013). Factor Components of Inequality: A Cross-Country Study. The Review of Income and Wealth, 59(4), 689-727. DOI: 10.1111/roiw.12054.

20. Aaberge, R. (1995). Choosing Measures of Inequality for Empirical Applications. Discussions Papers No. 158. Retrieved from: https://www.ssb.no/a/publikasjoner/pdf/DP/dp_158.pdf (Date of access: 25.04.2019).

21. Ciuleviciene, V. (2007). Gini Coefficient and Its Application for the Measurement of Economic Inequality. Vagos, 77(30), 45-51. (In Lith.)

22. Kuznets, S. (1955). Economic Growth and Income Inequality. The American Economic Review, 45(1), 1-28.

23. Neves, P. C. \& Silva, S. M. T. (2014). Inequality and Growth: Uncovering the Main Conclusions from the Empirics. Journal of Development Studies, 50(1), 1-21. DOI: 10.1080/00220388.2013.841885.

24. Turnovsky, S. J. (2013). The Relationship Between Economic Growth and Inequality. New Zealand Economic Papers, 47(2), 113-139. DOI: 10.1080/00779954.2013.776483. 
25. Roshchina, J. (2005). Income Inequality and Education in Russia. Voprosy obrazovaniya [Educational Studies Moscow], 4, 274-296. (In Russ.)

26. Balatskiy, E. V. \& Saakyants, K. M. (2006). Divergentsiya Dohodov i Ekonomicheskiy rost. Nauchnye trudy: Institut narodnokhozyaystvennogo prognozirovaniya RAN [Scientific Articles - Institute of Economic Forecasting RAS]. Retrieved from: https://cyberleninka.ru/article/n/divergentsiya-dohodov-i-ekonomicheskiy-rost/viewer (Date of access: 25.04.2019). (In Russ.)

27. Card, D. (2009). Immigration and Inequality. American Economic Review, 99(2), 1-21. DOI: 10.1257/aer.99.2.1.

28. Bourguignon, F. \& Morrisson, C. (2002). Inequality Among World Citizens: 1820-1992. American Economic Review, 92(4), 727-744. DOI: 10.1257/00028280260344443.

29. Ali, A. A. G. (1998). Dealing with Poverty and Income Distribution Issues in Developing Countries: Cross-Regional Experiences. Journal of African Economies, 7(2), 77-115. DOI: 10.1093/jafeco/7.suppl_2.77.

30. Tirado, D. A., Diez-Minguela, A. \& Martinez-Galarraga, J. (2016). Regional Inequality and Economic Development in Spain, 1860-2010. Journal of Historical Geography, 54, 87-98. DOI: 10.1016/j.jhg.2016.09.005.

31. Lessmann, C. \& Seidel, A. (2017). Regional Inequality, Convergence, and Its Determinants - A View from Outer Space. European Economic Review, 92, 110-132. DOI: 10.1016/j.euroecorev.2016.11.009.

32. Bellu, L. G. \& Liberati, P. (2006). Inequality Analysis. The Gini Index. EASYPol. Retrieved from: http://www.fao. org/3/a-am352e.pdf (Date of access: 01.03.2019).

33. Sen, A. \& Foster, J. E. (1997). On Economic Inequality (2nd ed.). Oxford: Oxford University Press, 280.

34. De Maio, F. G. (2007). Income Inequality Measures. Journal of Epidemiology \& Community Health, 61(10), 849-852. DOI: 10.1136/jech.2006.052969.

35. Butkus, M. \& Matuzeviciute, K. (2011). Evaluation of Economic Territorial (Regional) Disparities in Countries of the European Union. Economics and management: Current Issues and Perspectives, 3(23), 66-79. (In Lith.)

\section{About the authors}

Daiva Laskiene - Dr. Sci. (Econ.), Associate Professor, School of Economics and Business, Kaunas University of Technology; https://orcid.org/0000-0001-5224-5040 (50, Gedimino St., Kaunas, 44239, Lithuania; e-mail: daiva.laskiene@ ktu.lt).

Irena Pekarskiene - Dr. Sci. (Econ.), Professor, School of Economics and Business, Kaunas University of Technology; https://orcid.org/0000-0001-8710-4731 (50, Gedimino St., Kaunas, 44239, Lithuania; e-mail: irena.pekarskiene@ktu.lt).

Rima Kontautiene - Dr. Sci. (Econ.), Lecturer, School of Economics and Business, Kaunas University of Technology; https://orcid.org/0000-0003-1881-3424 (50, Gedimino St., Kaunas, 44239, Lithuania; e-mail: rima.kontautiene@ktu.lt).

\section{Информация об авторах}

Ласкиене Дайва - доктор экономических наук, доцент, школа экономики и бизнеса, Каунасский технологический университет; https://orcid.org/0000-0001-5224-5040 (Литва, 44239, г. Каунас, ул. Гядмино, 50; e-mail: daiva.laskiene@ktu.lt).

Пекарскиене Ирена - доктор экономических наук, профессор, школа экономики и бизнеса, Каунасский технологический университет; https://orcid.org/0000-0001-8710-4731 (Литва, 44239, г. Каунас, ул. Гядмино, 50; e-mail: irena.pekarskiene@ktu.lt).

Контаутиене Рима - доктор экономических наук, преподаватель, школа экономики и бизнеса, Каунасский технологический университет; https://orcid.org/0000-0003-1881-3424 (Литва, 44239, г. Каунас, ул. Гядмино, 50; e-mail: rima.kontautiene@ktu.lt).

Дата поступления рукописи: 12.07.2019.

Прошла рецензирование: 05.11.2019.

Принято решение о публикации: 15.09.2020.

Received: 12 Jul 2019.

Reviewed: 05 Nov 2019. Accepted: 15 Sep 2020. 